\title{
KONSEP PENDIDIKAN KELUARGA SAKINAH
}

\author{
Oleh: Sutinah
}

Sekolah Tinggi Agama Islam Masjid Syuhada Yogyakarta

\begin{abstract}
Love is not a noun, but a verb. Ursula $K$. Leguin is quoted by Khoiruddin Bashori in his paper said that love is not like a stone, which suddenly sitting somewhere, but like a bread that must be made and always have to be renewed. If marriage begins with love, actually is a good start. And then depends on how it continually renewed and also nurtured. In psychological, the term "fall in love" actually are not appropriate. Love is not falling but giving. We are not falling in love but making love. In other words, we must behave with compassion so that love can grow well. A husband gives love to his wife as well as the wife gives it to her husband. Like an investment, the more we give to our spouse then our love will be thicker to his/her. We can not passively, waiting for love to bloom by itself. In order to make our household become stronger it needs an efforts for both wife and husband to improve the emotional maturity, tolerancy, respect, common interest and values, ability to responsible for economic, ability to solve problems and also conflict resolution. So, it is very important to a couple provide times to talk and share about the needs for self and spouse. Happy family welfare typically formed through several stages. A family should be able to pass the stages one by one well. But some are not be able to reach the final stage that is a happy family. Happy family which is a family that everyone wants, is a family with full of love.
\end{abstract}

Cinta bukan kata benda, tapi kata kerja.Ursula K Leguin yang dikutip Khoiruddin Bashori dalam makalahnya mengatakan Cinta bukan separti batu, yang tiba-tiba teronggok disuatu tempat, tapi seperti roti, yang harus 
dibikin, dibikin lagi setiap waktu diperbaharui. Jika perkawinan diawali dengan saling mencintai, sebanarnya sudah merupakan modal yang sangat bagus, tinggal bagaimana itu terus diperbaharui, dipupuk. Istilah jatuh cinta sebenarnya kurang tepat secara psikologis. Cinta itu bukan jatuh, tapi memberi . kita tidak jatuh cinta tapi membuat cinta. Dengan kata lain kita mesti berperilaku dengan penuh cinta kasih, agar cinta dapat tumbuh subur. suami memberikan cinta kasih pada isteri ,demikian pula istri memberi kepada suami. Seperti layaknya sebuah investasi, semakin besar yang kita berikan kepada isteri/suami, semakin tebal perasaan cinta kita kepadanya. Kita tidak bisa pasif, menunggu cinta itu mekar dengan sendirinya. Agar bangunan rumah tangga itu semakin kokoh diperlukan pula berbagai upaya untuk meningkatkan kematangan emosi masing-masing, toleransi, respek, kesamaan minat dan nilai-nilai, kemampuan bertanggung jawab termasuk secara ekonomi, dan kemampuan problem solving dan penyelesaian konflik. Untuk itu sangat penting suami isteri perlu menyediakan waktu untuk berbicara dan mendengarkan apa kebutuhan diri dan pasangannya. Keluarga bahagia sejahtera biasanya terbentuk melalui beberapa tahapan, keluarga mestinya dapat dengan baik melewati tahap-tahap itu satu demi satu, namun ada pula yang tidak dapat mencapai tahap terakhir yaitu keluarga sakinah sebuah keluarga yang di inginkan semua orang yaitu sebuah keluarga yang penuh cinta kasih.

\section{A. Pendahuluan}

Agama Islam merupakan agama yang dengan syari'at atau hukum secara lengkap memberi tuntunan dan bimbingan bagaimana cara membangun, membina kehidupan keluarga menjadi tenang, tenteram dan 
penuh keberkahan.Kedamaian dan ketenteraman rumah tangga yang diteladani oleh ayah dan ibu, dapat memperlancar proses pendidikan dalam pola asuh sehingga anak merasa terpenuhi secara fisik maupun psikis, diantaranya kebutuhan berupa materi dan kejiwaan yaitu rasa aman dan kasih sayang.

Perkembangan zaman pada sekarang ini membawa pengaruh yang sangat signifikan pada kehidupan manusia, boleh dikatakan sekarang ini banyak kemajuan baik segi positif maupun segi negatifnya.Dampak positif manusia mendapatkan banyak kemudahan dengan adanya kemajuan teknologi, sebagai contoh orang mampu melihat dunia dengan satu sentuhan dengan perangkat komputer dan kecanggihan internet. Dampak negatif terhadap pergeseran nilai-nilai moral yang melekat pada diri seseorang yang mengubah manusia untuk menuju kebaikan ataupun membawa kepada kehancuran.

Pendidikan karakter seseorang terbentuk sejak dini, dalam hal ini keluargalah yang sangat berpengaruh dalam pendidikan anak, karena keluarga merupakan kelompok sosial terkecil dalam masyarakat. Keluarga terdiri (ayah-ibu dan anak) harus mengajarkan kepada anak agar dapat memahami, menghayati budaya yang berlaku dalam masyarakat. Karena keluarga menjalankan peranannya sebagai suatu sistem sosial yang dapat membentuk karakter serta moral seorang 
anak. Keluarga tidak hanya sebuah wadah tempat berkumpulnya ayah- ibu dan anak, tetapi lebih dari itu yaitu harus menanamkan pendidikan agama dan menjadi teladan bagi anak-anak.

Manusia adalah makhluk yang dapat mendidik dan dididik, sedang mahluk lainnya tidak, sehingga manusia memiliki potensi yang dapat menjadi subjek maupun objek mengembangkan diri, yang dalam kenyataannya mereka mampu berpikir, memiliki kebebasan berekpresi atau berkebudayaan,sebagai makhluk Allah dimuka bumi dengan tugas memakmurkan bumi dengan sebaikbaiknya.Untuk mencapai kemuliaan martabat manusia perlu menundukkan hawa nafsunya sendiri, pada waktu tertentu mendorong pada ketidak serasian, sifat tergesagesa, tidak berterima kasih,selalu berkelu kesah, berbuat kedhaliman, kemukaran dan sejenisnya. Kelemahan dalam diri manusia bukanlah menunjukkan bahwa manusia dilahirkan dalam keadaan terkutuk, atau memikul dosa warisan, namun dalam persepektif Islam tetap dilahirkan dalam kaadaan fitrah yakni suci, bersih, bebas dari dosa turunan, dan memiliki kecenderungan menerima agama, iman dan tauhid. ${ }^{1}$ oleh karena itu manusia menjadi baik atau buruk bisa ditinjau akibat pendidikan dan lingkungan, bukan tabiat aslinya. maka dari itu tugas orang tua, pendidik dan

1 Sumarno, Pola kehidupan Keluarga Cerai dan dampak psikologis terhadap siswa,( Program pasca sarjana UMY Jogyakarta th2013),hlm.4. 
pemimpin yang ikut bertanggung jawab terhadap generasi kedepannya.

\section{B. Pengertian Keluarga Sakinah}

Keluarga adalah kelompok sosial kecil dimana kita dapat merasakan berbagai cinta. Cinta pada ayah,ibu, adik, kakak, nenek, suami atau isteri, anak-anak dan cinta kepada seluruh anggota keluarga kita yang lainnya, keluarga lazimnya disebut rumah tangga yang merupakan unit terkecil dalam masyarakat sebagai wadah dan proses pergaulan hidup.

Menurut para ahli keluarga berarti satu kesatuan (unit) yang anggotanya mengabdikan diri kepada kepentingan dan tujuan unit tersebut. Keluarga juga terdiri dari beberapa pengertian diantaranya menurut hurlock keluarga adalah lingkungan pendidikan pertama dan utama bagi anak. Keluarga juga berfungsi sebagai transmater budaya atau mediator sosial anak. ${ }^{2}$ sedangkan kata sakinah menurut Zaitunah Subhan, kata sakinah mempunyai arti ketenangan dan ketentraman jiwa. ${ }^{3}$ Dalam surat Al-Baqarah ; 248 Allah Swt berfirman :

Artinya: "Dan Nabi mereka mengatakan kepada mereka; sesungguhnya tanda ia akan menjadi raja, ialah

\footnotetext{
2Sadiman, Arief. Dkk. Media pendidikan:pengertian, pengembangan, dan pemanfaatannya,(Jakarta: Raja Grafindo Persada, th 2009),hlm.6.

3 Zaen, Emma \& Sati, Djaka Dt. Ilmu mendidik( jakarta : Mutiara Sumber widya, th 1997, hlm.3.
} 
kembalinya tabut kepadamu, didalamnya terdapat ketenangan dari tuhanmu dan sisa dari peninggalan keluarga Musa dan keluarga Harun; tabut itu dibawa oleh Malaikat. Sesungguhnya pada yang demikian itu terdapat tanda bagimu, jika kamu orang yang beriman". 4

Secara bahasa, sakinah mawaddah dan rahmah berarti ketenangan, cinta suci dan kasih sayang. Ini berarti bahwa pernikahan yang disyariatkan dalam Islam bertujuan untuk mewujudkan ketenangan dalam diri anggota keluarga yang berlandaskan cinta dan kasih sayang yang suci. Oleh karena itu, ketenangan cinta suci dan kasih sayang yang hakiki tidak mungkin terwujud kecuali berlandaskan pada ketaatan kepada Allah dan Upaya untuk meraih keridhaan Nya.

Keluarga sakinah juga tertera dalam firman Allah SWT Q.S.AR-Ruum, 21 Artinya :" Dan Di antara tandatanda kekuasaanNya ialah Dia menciptakan untukmu istri-istri dari jenismu sendiri, supaya kamu cenderung dan merasa tenteram kepadanya, dan dijadikannya diantaramu rasa kasih dan sayang. Sesungguhnya pada yang demikian itu benar-benar terdapat tanda-tanda bagi kaum yang berfikir". ${ }^{5}$

${ }^{4}$ Departeman Agama RI, Al- Qur'an dan terjemahan, (Semarang.CV. Asy Syifa, th. 1999, hlm.61.

5 Ibid hlm. 644 
Segala bentuk kebaikan dan kebahagiaan yang diinginkan manusia ada ditangan Allah dan dialah yang memilikinya. Rasulullah Saw mengisyaratkan hal ini dalam Doa beliau: "Ya Allah kebaikan itu semua ada ditanganmu, dan keburukan itu tidak ada padamu."6

Dalam banyak ayat al-Qur'an, Allah menegaskan bahwa, segala bentuk kebaikan, kebahagiaan dan ketenangan dalam hidup manusia, hanya akan diraih dengan memahami dan mengamalkan petunjuk Allah, barang siap berpaling dari petunjuk Allah maka kesengsaraan dan kesempitan lah yang akan menghampirinya sebagaimana Firman Allah QS An-Nahl : 97 yang Artinya : "Barangsiapa yang mengerjakan amal saleh, baik laki-laki maupun perempuan dalam keadaan beriman, maka sesungguhnya akan kami berikan kepadanya kehidupan yang baik dan sesungguhnya akan kami berikan balasan kepada mereka dengan pahala yang lebih baik dari apa yang telah mereka kerjakan". 7

Dan firman Allah dalam QS Ar-Ra"du : 28 yang Artinya: "Orang-orang yang beriman dan hati mereka menjadi tenteram dengan berzikir ( mengingat ) Allah, Ingatlah hanya dengan mengingat Allah hati menjadi tenteram."8

${ }^{6}$ Hadits Riwayat. Muslim no. 771

7 Op. cit.hlm.458

8 Ibid. hlm. 373 
Semua bentuk cinta dan kasih sayang berasal dari Allah dan Allah yang melimpahkan semua itu kepada manusia, sehingga tidak mengkin cinta dan kasih sayang yang hakiki dapat terwujud dalam keluarga jika mereka berpaling dari Allah yang Maha Pengasih dan Maha Penyayang.

\section{Proses Terbentuknya Keluarga Sakinah}

Sebuah keluarga tidak akan mungkin terwujud tampa adanya pernikahan, karena pernikahan adalah Sunnah Nabi, oleh sebab itu Islam menganjurkan umatnya untuk menikah, karena nikah termasuk qharizah insaniyyah (naluri kemanusiaan). Apa bila naluri ini tidak terpenuhi dengan jalan yang benar yaitu pernikahan maka iapun mencari jalan yang tidak benar yaitu jalan yang dibimbing oleh syetan yaitu jalan yang membawa ke lembah hitam.

Sebagaimana Firman Allah QS Ar-Rum: 30 artinya: "Maka hadapkanlah wajahmu dengan lurus kepada agama (Allah); ( tetaplah atas ) firman Allah yang telah menciptakan manusia menurut fitrah itu. Tidak ada perubahan pada fitrah Allah.( itulah ) Agama yang lurus; tetapi kebanyakan manusia tidak mengetahui" 9 .

Ilmu merupakan salah satu kunci untuk meraih kebahagiaan keluarga. Semakin banyak ilmu yang dimiliki maka semakin besar peluang terwujudnya

9 Ibid. hlm. 491 
sebuah keluarga bahagia sebagaimana diungkapkan oleh Ustad Awan Abdullah dalam kajiannya dikampus STAIMS Syuhada Jogjakarta. Karena ilmu akan menjadikan suami istri lebih bijak menghadapi dinamika kehidupan berkeluarga, menurut Ustad Awam Dalam kajian bertema Ketika Hati Rindu Menikah, konteks Islam menikah tidak perlu melalui peroses pacaran.menurutnya pacaran tidak menjamin terciptanya keluarga yang bahagia dan harmonis jika ahirnya pasangan itu benar-benar menjadi pasangan suami istri." Tidak ada yang jamin", yang banyak terjadi akhir-akhir ini, justru pasangan pasangan yang dulunya pakai tahap pacaran malah cerai, pasangan yang tidak pacaran justru langgeng.

Kunci lain untuk meraih keluarga bahagia adalah kepribadian yang baik. Suami istri jangan terlalu menuntut terhadap pasangan, selain itu berprilaku yang santun dan saling menghormati

Kehadiran agama Islam sebagai rahmatan lil'alamin dengan seperangkat pedoman dan dasar hukum yang menjadikan manusia lebih mudah meniti jalan untuk membina kehidupan keluarga bahagia lahir dan bathin, lestari dan kokoh, sepanjang waktu. Ada ayat-ayat alqur'an dan beberapa hadits memberikan tuntunan tentang pemilihan jodoh, peminangan,pernikahan, hak suami,hak istri,hak anak serta pengasuhnya. Hal ini bertujuan antara lain agar kohesi sosial antara anggota 
keluarga menjadi erat dan lekat, sehingga akan mempermudah terjadinya transfer nilai-nilai kehidupan dalam tatanan rumah tangga. ${ }^{10}$

\section{Pendidikan Dalam Keluarga Sakinah}

Menciptakan generasi yang baik harus mengubah lingkungan keluarga menjadi nyaman, tenteram, sesuai dengan nilai-nilai Agama. Sehingga terwujud generasi yang berdasar pada pola kehidupan yang sudah tertanam dalam keluarga tersebut ,yang demikian tidak akan terwujud kecuali anggota keluarga paham tentang dasar-dasar berkeluarga yang benar. Perkembangan karakter seorang anak dipengaruhi oleh perlakuan keluarga dalam mendidiknya.

Keluarga memiliki peranan penting dalam meningkatkan kualitas sumber daya manusia. Pendidikan moral dalam keluarga perlu ditanamkan sejak dini pada setiap individu.setiap keluarga pasti memiliki keinginan untuk mewujudkan keluarga yang "Sakinah Mawaddah wa rahmah" sehingga setiap anggota keluarga harus memiliki peran dalam menjalankan amanahnya, suami sebagai kepala rumah tangga harus memberikan teladan yang baik dalam mengemban tanggung jawabnya, karena kelak Allah Swt akan mempertanyakan tanggung jawabnya pada hari kiamat nanti.

10 Op.cit. hlm.30. 
Tanggung jawab orang tua terhadap anak-anaknya adalah :

1. Secara baik dan sabar mendidik anak agar mancintai Allah dan Rusulnya yaitu mengajarkan tauhid kepada nya, bagaimana mentauhidkan Allah dan menjauh kan larangan dari perbuatan syirik. Sebagaimana nasihat Luqman kepada anaknya : QS Luqman : 13. Yang artinya : Dan( ingatlah ) ketika luqman berkata kepada anaknya, diwaktu ia memberi pelajaran kepadanya : "Hai anakku, janganlah kamu mempersekutukan Allah, sesungguhnya mempersekutukan ( Allah ) adalah benar-benar kedzaliman yang besar. ${ }^{11}$

2. Mengajarkan kalimat yang baik serta bacaan alQur'an sejak dini kepada anak.

Pada usia balita ( sekitar 2-5 tahun ), ajarkan kepada mereka kalimat-kalimat yang baik serta bacaan alQur'an. Sebagaimana dicontohkan para sahabat serta generasi Tabi'in dan Tabi'ut Tabi'in, sehingga banyak dari mareka yang hafal Al-Qur'an pada usia muda.

3. Memperioritaskan perhatian pada shalat dalam pendidikan anak.

Rasullullah Swt bersabda Yang Artinya : Suruh anak kalian shalat ketika berumur tujuh tahun, dan kalau sudah berusia sepuluh tahun meninggalkan sholat,

11 Op .cit, hlm.81. 
maka pukullah ia, dan pisahkanlah tempat tidurnya ( antara anak laki-laki dan anak prempuan). ${ }^{12}$

4. Perhatian orang tua kepada anaknya dalam pembentukan akhlak yang mulia.

Akhlak yang baik atau mulia memiliki kedudukan yang tinggi di dalam Islam. Nabi Muhammad Saw menjelaskan bahwa yang banyak memasukkan manusia ke surga adalah ketaqwaan kepada Allah Swt dan akhlak yang mulia. Sebagaimana dijelaskan bahwa : Rasulullah ditanya tentang kebanyakan yang menyebabkan manusia masuk surga, maka beliau menjawab :" Taqwa kepada Allah dan akhlak yang baik " Dan ketika ditanya tentang kebanyakan yang menyebabkan manusia masuk neraka, maka beliau menjawab : "Mulut dan Kemaluanmu” .13

5. Mengawasi pergaulan Anak demi menjaga Agamanya.

Perlu diperhatikan pula teman pergaulan anak, karena pengaruh buruk dari temannya akan ditiru oleh anak-anak kita sebagaimana Rasullullah Saw bersabda, yang artinya :" Seseorang bergantung pada agama teman karibnya. Maka hendaklah seorang dari kalian melihat siapa temannya."14

12 Imam ahmad bin Hambal asy- syaibani, Musnad Ahmad, (Beirut : Dar al-fikr.tt ), hlm.180-187.

13 Muhammad Nashirudin al-Albani, Shahihal- Adaabul Mufrad, (Arabiya : Dar Ash shidiq, 1415 H.) no.289.

${ }^{14}$ HR. Abu Dawud no.4833,Syaikh al-Albani dalam silsilah al-Ahaddist ash-Shahihah ( Riyadh : maktabah Ma'arif, tt) no.927. 
6. Berdoa kepada Allah untuk anak dan keluarga pada setiap waktu yang mustajab

Hendaknya Seorang suami memanjatkan Doa kepada Allah Swt pada waktu yang mustajab, tujuannya supaya keluarga dijadikan keluarga yang Sakinah mawaddah wa rahmah, agar istri dan anakanaknya dijadikan orang-orang yang shaleh shalihah serta bertaqwa kepada Allah Swt.

7. Mengajarkan Doa-doa dan dzikir Hendaklah orang tua mengajarkan anak-anaknya berbagai doa dan dzikir pagi dan sore yang mudah dihafal. Doa dan dzikir sangat bermanfaat diajarkan pada anak-anak. Yang semua itu dilakukan sebagai pengalaman, Sunnah Nabi Saw dan juga penjagaan diri dari godaan syetan. 15

Kesalahan Dalam Mendidik Anak yang dilakukan orang tua adalah :

1. Kekejaman dan kekerasan

Para ahli pendidikan dan pakar kejiwaan memandang cara ini sebagai cara yang paling berbahaya bagi anak apabila terlalu sering dilakukan. Takkala sang pendidik emosi hingga kehilangan kontrol, sehingga melupakan kesabaran dan kelapangan hati, menyerang sianak dan mencaci

15 Zazid bin Abdul Qadir Jawas, Doa dan wirid dan dzikir pagi dan petang; (Jakarta Pustaka Imam Syafi'i), hlm.46. 
makinya. Hal ini akan mengakibatkan anak menjadi benci untuk belajar atau menolak tanggung jawab.

2. Kemanjaan yang berlebihan dan sikap pernisif

Sikap terlalu melindungi dan memanjakan hanya akan membuat sianak merasa tidak mampu menjalin hubungan sosial yang sukses dengan orang lain, tidak mampu mengemban tanggung jawab dan menghadapi kenyataan hidup. Dalam hal ini tidak juga diinginkankan agar orang tua mencabut kasih sayang dari hatinya. Karena anak membutuhkan kasih sayang tetapi tidak melampawi batas namun haruslah dengan pertimbangan dan kewaspadaan.

Rasullullah Saw bersabda, yang berbunyi : Bukanlah termasuk golongan kami seseorang yang tidak mengerti hak yang lebih tua dan tidak menyayangi yang lebih muda. ${ }^{16}$

3. Tidak konsisten dalam bertindak

Anak perlu mengerti apa yang diharapkan dari dirinya, oleh karena itu orang tua harus memberikan aturan-aturan yang mudah dimengerti dalam penjelasan yang logis serta menerangkannya kepada anak secara jelas.

4. Sikap tidak adil pada anak-anak yang bersaudara.

Orang tua terkadang tidak adil memperlakukan anak dengan mengutamakan seorang anak dengan

16 Muhammad Nashirudin al-Albani, shahihal-Adaabul Mufrad, op .cit, no. 271 
anak-anak yang lain. Sikap ini akan memicu kecemburuan saudaranya yang lain. Hal ini Rasulullah Saw bersabda" bertaqwalah kelian kepada Allah dan berlaku adillah terhadap anakanak kalian" 17

\section{E. Islam Menganjurkan Menikah}

Penghargaan Islam terhadap ikatan pernikahan besar sekali, Allah SWT menyebutkan sebagai ikatan yang kuat dengan firmannya : Bagaimana kamu akan mengambilnya kembali. Padahal sebagian kamu telah bargaul ( bercampur ) dengan yang lain sebagai suami istri“Dan mereka( istri-istrimu telah mengambil dari kamu perjanjian yang kuat ( QS, An Nisaa' : 21). ${ }^{18}$

Sampai-sampai ikatan itu ditetapkan sebanding dengan separuh agama, sebagaimana sabda Rasulullah Saw : "Barang siapa menikah, maka ia telah melengkapi separuh dari agamanya. Dan hendaklah ia bertaqwa kepada Allah dalam memelihara yang separuhnya lagi. 19

Rasullullah Saw memerintahkan untuk menikah dan melarang keras kepada orang yang tidak mau menikah. Anas bin Malik Ra berkata : "Rasullullah Saw memerintahkan kami untuk menikah dan melarang kami membujang dengan larangan yang keras.

17 HR Bukhari, Shahih Al Bukhari, op.cit, no. 2587.

18 Op.cit.hlm.120.

19 HR Ath-Thabrani, Mu' jamul Ausath, (Riyadh: Maktabah al-Ma'arif, $1405 \mathrm{H})$, no.625. 
Rasullullah Saw bersabda, "Nikahilah wanita yang subur dan penyayang, karena aku akan berbangga dengan banyaknya umatku dihadapan umat-umat di hari kiamat. ${ }^{20}$

Pernah suatu ketika, tiga orang sahabat datang bertanya kepada Istri-istri Nabi Saw, tentang peribadatan beliau,, masing-masing ingin meningkatkan ibadah mereka, salah seorang dari pada mereka berkata: "Adapun saya akan puasa sepanjang masa tanpa putus." Sahabat yang lain berkata; adapun saya akan menjauhi wanita, saya tidak akan nikah selamanya, ketika hal itu didengar oleh Nabi Saw Beliaupun keluar seraya bersabda, yang artinya: Benarkah kalian telah berkata begini dan begitu? "Sungguh demi Allah, sesungguhnya akulah yang paling takut dan taqwa kepada Allah diantara kalian, akan tetapi aku berpuasa dan aku berbuka, aku shalat dan aku juga tidur dan aku juga tidur dan aku juga menikah wanita. Maka barang siapa yang tidak menyukai sunnahku, maka ia tidak termasuk golonganku". ${ }^{21}$

Rasullullah Saw. Menyatakan bahwa seseorang yang ingin hidupnya memperoleh ketenangan dan kebaikan, maka hendaklah ia memiliki tiga hal. Pertama, ia harus memiliki istri yang shalehah. Kedua, memiliki

20 Ibnu Hiban, Mawariduzh zham'an ila zawa'id, (Beirut: Daral Kutub ilmiyah.tt),no. 1228 . no.5063.

21 HR Bukhari, Shahih Al Bukhari, (Kairo; Darul al-Hadits, 1422H), 
kendaraan yang baik, dan pada zaman Rasullullah kendaraan yang baik ini ialah kuda. Dan yang ketiga, memiliki rumah. Mendapatkan istri shalihah, kendaraan yang bagus sebagai alat trasportasi, dan rumah sebagai tempat tinggal merupakan kebutuhan dasar manusia. Oleh karena itu, apbila seseorang telah memiliki ketiga macam kebutuhan tersebut dengan sempurna, dia akan bisa memperoleh kasenangan dalam hidupnya. ${ }^{22}$

\section{F. Tujuan Pernikahan dalam Islam}

Pernikahan adalah ikatan yang mulia dan diberkahi. Allah Swt telah mensyari'atkan pernikahan untuk kemaslahatn dan kemanfaatan hamba-hambanya, agar dengannya mereka dapat mencapai maksudmaksud yang baik dan tujuan yang mulia.

Tujuan dari sebuah pernikahan yaitu :

1. Untuk memenuhi tuntutan naluri manusia

Pernikahan adalah fitrah manusia, maka jalan yang sah untuk memenuhi kebutuhan biologis adalah dengan menikah, bukan dengan cara yang dilarang oleh agama, seperti dengan cara yang dilakukan orang-orang sekarang ini, contohnya : pacaran, kumpul kebo, melacur. Berzina, lesbi, homo dan sebagainya.

22 Muhammad thalib,Manajemen Keluarga Sakinah(Penerbit,Pro-U cetakan ke2 th2008),hlm.87. 
2. Untuk membentengi akhlak yang luhur dan menundukkan pandangan

Sasaran utama disyari'atkannya pernikahan dalam Islam diantaranya adalah untuk membentengi martabat manusia dari perbuatan kotor dan keji, yang dapat merendahkan dan merusak martabat manusia, Islam memandang pernikahan dan pembentukan keluarga sebagai sarana efektif untuk memelihara pemuda dan pemudi dari maksiat dan melindungi martabat manusia kedepan.

3. Untuk menegakkan rumah tangga yang Islami

Dalam Al-Qur'an disebutkan bahwa Islam membenarkan adanya thalaq, (perceraian, jika suami istri sudah tidak sanggup lagi menegakkan batasbatas Allah, Sebagaimana Firman Allah, QS. AlBaqararah : 229. Yang artinya : Thalaq ( yang dapat dirujuki) itu dua kali. setelah itu boleh rujuk lagi dengan cara yang ma'ruf atau menceraikan dengan cara yang baik. Tidak halal bagi kamu mengambil kembali sesuatu dari yang telah kamu berikan kepada mereka, kecuali kalau keduanya khawatir tidak akan dapat menjalankan hukum-hukum Allah, maka tidak ada dosa atas keduanya tentang bayaran yang diberikan oleh istri untuk menebus dirinya. Itula hukum-hukum Allah, maka janganlah kamu melanggarnya, barang siapa yang melanggar hukum- 
hukum Allah mereka itulah orang-orang yang zalim. 23

4. Meningkatkan Ibadah Kepada Allah

Menurut konsep Islam, hidup sepenuhnya untuk mengabdi dan sesama manusia. Rumah tangga adalah salah satu lahan subur bagi peribadahan dan amal shaleh di samping amal-amal yang lainnya. Bahkan hubungan suami istripun termasuk ibadah dan (sedekah) sebagaimana Rsullullah bersabda yang artinya : "Seseorang di antara kalian bersetubuh dengan istrinya adalah sedekah "(mendengar sabda Rasullullah, para Shahabat keheranan ) lalu bertanya : "Wahai Rasullulllah, apakah salah seorang dari kita melampiaskan syahwatnya terhadap istrinya akan mendapat pahala? "Nabi Saw menjawab : Bagaimana menurut kalian jika ia ( seorang suami ) bersetubuh dengan selain istrinya, bukankah ia berdosa ? begitu pula jika ia bersetubuh dengan istrinya (ditempat yang halal), Dia akan memperoleh pahala."24

5. Memperoleh Keturunan yang shaleh.

Tujuan pernikahan diantaranya adalah memperoleh keturunan yang shaleh Sholehah yakni untuk menjaga eksestensi dan memperbanyak Bani

23 Departemen Agama RI,Alqur'an dan Terjemahan, Opcit, hlm.55.

24 Muhammad Nasirudin al-Albani, ,( Arabiyah : Dar Ash-Shidiq, 1405),no. 227 
Adam sebagaimana firman Allah Swt, Q .S. An-Nahl : 72. Artinya : "Allah menjadikan bagi kamu istriistri dari jenis kamu sendiri dan menjadikan bagimu dari istri-istri kamu itu, anak-anak dan cucu-cucu, dan memberimu rezeki dari yang baik-baik. Maka mengapakah mereka beriman kepada yang bathil dan mengingkari ni'mat Allah". 25

Dalam pernikahan bukan hanya sekedar memperoleh anak, tetapi berusaha mencari dan membentuk generasi yang berkualitas, yaitu menjadi anak shaleh dan sholehah dan bertaqwa kepada Allah Swt.

1. Nilai Keluarga

Islam merupakan agama fitrah, agama yang selalu sesuai dengan tabiat dan dorongan batin manusia. Islam dapat memenuhi dorongan-dorongan batin manusia dengan menempatkan dorongandorongan tersebut pada garis syariat Islam. Dorongan batin untuk mengadakan kontak antar jenis laki-laki dan perempuan diatur dalam syari'at perkawinan. Masalah ini menjadi perhatian utama Islam sehingga dorongan tersebut diberi aturan hukum yang disebut hukum perkawinan. Islam telah menegaskan bahwa hanya perkawinan inilah satusatunya cara yang sah membentuk hubungan antara laki-laki dan perempuan dalam membangun suatu

25 Departemen AgamaRI, al Qur'an dan terjemahan, hlm.412 
masyarakat yang berperadaban, 26 sebagai mana firman Allah dalam Q.S. An-Nuur : 32, yang artinya ; "Kawinkanlah bujangan-bujangan yang telah layak untuk kawin dari antara para budak laki-laki dan perempuan kamu. Jika mereka miskin, Allah kelak akan memberikan kecukupan kepada mereka dari rizki-Nya dan Allah Mahaluas ( rizki-Nya) dan maha tahu." 27

Sebagaimana Rasullullah Saw. Bersabda: "Siapa saja yang mencintai fitrahku (ajaranku )hendaklah ia mengikuti teladan hidupku; dan diantara teladan hidupku adalah menikah (H.R. Bayhaqi) ${ }^{28}$.

2. Falsafah berkeluarga

a. Zauj : Artinya genap, Setiap pasangan merasa dirinya belum genap jika tidak bergabung dengan yang lainnya sehingga perlu adanya kerjasama semua pihak.

b. Libas (pakaian) Masing-masing pasangan menjadi pakaian bagi yang lainnya. Pakaian berarti menutupi aib/kekurangan. (menghangatkan, menjaga dari kepanasan atau kedinginan).

c. Isteri adalah "HARTS" atau tanaman, Tanaman adalah tanah yang perlu dijaga, dirawat,

26 Muhammad Thalib, Manajemen Keluarga Sakinah (Penerbit Pro-U, cetakan ke-2, th 2008),hlm.29.

27 Op.cit,hlm. 549.

28 Op. cit, hlm. 30. 
diperhatikan, dipupuk agar tanaman menjadi subur dan menghasilkan yang maksimal.

d. Jangan lupa melihat kelebihan yang ada pada masing-masing pihak.

e. Sabda Nabi Saw sebaik-baiknya kamu adalah yang terbaik kepada isterinya / keluarga.

f. Kedamaian dalam keluarga akan menciptakan iklim yang kondusif bagi munculnya generasi yang baik.

g. Sesuatu hal kecil yang tidak mandasar tidak boleh diperbesar.

h. Mengerti apa yang tidak disukai masing-masing 29 .

\section{G. Langkah-langkah Mewujudkan Keluarga Sakinah}

Untuk dapat mewujudkan keluarga yang sakinah disamping memahami hak dan kewajibannya suami istri harus dapat melaksanakan beberapa hal yaitu :

1. Peningkatan pendidikan, baik kualitas maupun kwantitas antara lain;
a. Pendidikan ketauhidan
b. Pendidikan keterampilan
c. Pendidikan akhlak
d. Pendidikan kemandirian

2. Ekonomi keluarga yang setabil

a. Pengendalian keuangan

29 Seminar di Kemenag oleh Zamari,Bahan Ajar Pelatihan Korps Penasihat BP4,Tgl 26 Maret 2013. 
b. Membiasakan menabung

c. Membelanjakan sesuai dengan kebutuhan

d. Pemanfaatan keterampilan dan waktu luang untuk menambah pendapatan

e. Program pemberdayaan ekonomi umat dilaksanakan melalui peningkatan kegiatan kerakyatan seperti koperasi masjid, kelompok usaha, koperasi majlis taklim dan upaya pemberdayaan lainnya.

3. Kesehatan keluarga yang terjaga dengan baik antara lain :

a. Gizi keluarga terpenuhi, program ini dilaksanakan dengan memberikan motivasi dan bimbingan kepada keluarga dan masyarakat melalui pendekatan agama agar masyarakat mementingkan gizi yang baik bagi seluruh keluarga, antara lain dengan usaha keluarga untuk dapat memenuhi kebutuhan makanan yang mengandung empat sehat lima sempurna. Kegiatan ini juga difokuskan pada pemberian imunisasi, penanggulangan diare dan lainnya.

b. Program meningkatkan kesadaran keluarga Pola Hidup Bersih dan Sehat ( PHBS ) dalam keluarga antara lain ;

1) Pembiasaan buang sampah pada tempatnya,

2) Kebersihan bak mandi, pakaian

3) Sirkulasi udara dalam rumah 
4) Kebiasaan olah raga

5) Sanitasi lingkungan.

Program ini dilaksanakan melalui Pendekatan agama dengan memberikan motivasi, bimbingan bantuan penyediaan air bersih, jambanisasi, sanitasi, lingkungan masjid, mushola, kantor, tempat umum keluarga.

4. Mengupayakan terwujudnya kehidupan beragama dan ubudiyah (ibadah) dalam keluarga dengan menciptakan suasana keagamaan dalam keluarga dengan melakukan :

a. Pendidikan agama dalam keluarga.

Program ini pada prinsipnya dilakukan oleh ayah dan ibu dengan tujuan untuk menanamkan dan mengamalkan nilai-nilai keimanan dalam kehidupan sehari-hari dalam keluarga dan lingkungannya. Dalam hal orang tua karena sesuatu hal tidak mampu maka dapat dilaksanakan bimbingan agama secara terpadu dalam bentuk kelompok belajar agama. Diantaranya :

1) Membudayakan sholat berjemaah

2) Membiasakan membaca al-Qur'an

3) Mengadakan amliyah ubudiyah lainnya dalam kehidupan sehari-hari. 
5. Hubungan fungsional yang seimbang

a. Menjaga hubungan yang komunikatif antar keluarga

b. Membina akhlak mulia dalam keluarga

c. Menumbuhkan rasa memiliki dan kebersamaan

d. Mengembangkan kecintaan pada lingkungan

e. Upaya-upaya mewujudkan keharmonisan hubungan suami-isteri dalam membina keluarga sakinah; 1). Adanya saling pengertian, 2). Saling menerima kenyataan, 3). Saling menyesuaikan diri, 4). Memupuk rasa cinta, 5). Melaksanakan asas musyawarah, 6). Suka memaafkan, 7). Berperan serta untuk kemajuan bersama, 8). Kemitraan sejajar suami-isteri, 9). Saling memuji kelebihan dan menyempurnakan kekurangannya, 10). Memberikan hadiah, 11). Saling memberi nasihat, 12). Masing-masing mempungsikan diri, 13). Saling terbuka dan saling pengertian, 14). Menyatukan tujuan perkawinan, 15) Perkawinan bernilai ibadah. 30

Keluarga bahagia - sejahtera biasanya terbantuk melalui beberapa tahapan. Sementara keluarga dapat dengan baik melewati tahap-tahap itu satu demi satu, namun ada pula yang tidak mencapai tahap terakhir, yaitu keluarga sakinah. Sebuah keluarga yang penuh cinta kasih .

30 Op cit,hlm. 79-80. 
Menurut Dawn J. Lifthrott, yang dikutip oleh Khoiruddin Bashori dalam makalahnya menjelaskan pembentukan keluarga bahagia sejahtera biasanya ditempuh melalui lima tahap, ${ }^{31}$ yaitu : Cinta romantis, penyesuaian, pemahaman dan kesadaran, transformasi, dan cinta sejati. Pada awal pernikahaan, pasangan suami isteri memasuki bulan madu. Disebut bulan madu karena pada bulan madu ini kehidupan terasa begitu manis seperti madu.

Tahap Cinta romantis, ini semua nampak bagus, serba indah dan menyenangkan. Setiapangan suami isteri berharap agar bulan madu dapat berlansung selamanya. Namun harapan sering tidak cocok dengan kenyataan. Bersama berjalannya waktu, madu dapat berubah pahit. Wujud asli, jati diri masing-masing, mulai kelihatan. Benturan terjadi tak terelakkan. Pertengkaran terkadang merupakan menu harian.

Tahap penyesuaian, Suami isteri mulai melihat kenyataan yang sebenarnya, mengenai pasangan masing-masing. Impian-impian indah bulan madu, berganti dengan hadirnya sejumlah ketidak cocokan, ketidak puasan, atau bahkan perbedaan disinilah pentingnya peroses penyesuaian. Pada tahap ini suami isteri harus bersedia adjusting to reality, belajar menyesuaikan diri dengan realita yang sesungguhnya. Agar penyesuain lebih cepat berlansung, suami isteri

31 Khoiruddin Bashori, Makalah, Op cit ,hlm.3. 
perlu bersikap jujur dengan perasaan hatinya masingmasing. Katakan terus terang apa yang disukai dan tidak disukai, sudah barang tentu dengan cara bijaksana, kejujuran dan keterus terangan yang diperlihatkan pada tahap ini akan sangat membantu ketika suami-isteri memasuki tahap berikutnya.

Tahap pemahaman dan kesadaran muncul jika peroses penyesuaian dapat berlansung mulus. Pada tahap ini suami-isteri sudah dapat mengenali pasangannya secara lebih baik. Masing-masing lebih mengerti dengan kelebihan dan kekurangan diri dan pasangannya. Suami isteri dapat secara objektif menyadari posisi masing-masing. Banyak pasangan yang gagal dalam berkeluarga gara-gara salah satu pihak tidak mau mengakui kekurangannya. Kekurangan biasanya selalu ditimpakan pada pasangannya tidak pernah untuk dirinya sendiri.

Tahap transformasi, setelah pada tahap sebelumnya suami isteri menyadari kekuranganya masing-masing, hendaknya dilanjutkan dengan upaya transformasi, yaitu mengembangkan diri kearah kerangka ideal yang dicita-citakan dalam bahasa partai politik sering disebut Platform, harus dirumuskan dan disepakati bersama. Keluarga seperti apa yang mau dibangun, suami isteri ideal yang seperti apa yang diinginkan, bagaimana seharusnya mendidik anak dsb., 
adalah diantara sebagian poin penting yang harus disepakati.

Tahap Cinta sejati, yaitu keluarga yang penuh dengan suasana saling menghormati dan memberikan apresiasi yang mendalam satu sama lain. Sebuah keluarga yang menyenangkan, saling melayani dan mengasihi. Dalam keluarga seperti ini, suami - isteri merupakan sahabat terbaik bagi pasangannya.

\section{H. Kesimpulan}

Tujuan dari perkawinan dalam Islam adalah membina keluarga Sakinah Mawaddah Warahmah, untuk mencapai keluarga Sakinah tentu membutuhkan konsep Yaitu, Pertama dimulai dengan memilih pasangan hidup yang shalih sholehah dengan mengutamakan, keagamaannya setelah itu baru menimbang sisi yang lainnya.Kedua mengawali dengan menikah secara agama, karena dengan menikah akan timbul ketenangan,Ketiga Suami istri harus melaksanakan hak dan kewajiban dan memposisikan dirinya sesuai dengan tanggung jawab masingmasing.Keempat Keluarga harus senantiasa menjalankan sunnah-sunnah Nabi SAW dan menjalankan perintah Allah SWT serta menjauhi segala apa yang dilarangnya. Kelima Mendidik anggota keluarga dengan ilmu syar'i agar mereka mengerti batasanbatasan anjuran dan larangan untuk sebuah keluarga. 
Keenam Mendidik anak agar mencintai Allah dan Rarul yaitu dengan mengajarkan Tauhid kepadanya Ketujuh, Mangajarkan Al-gur'an sejak dini, dan memperioritas kan Sholat lima waktu ketika berumur tujuh tahun. Kedelapan menenanamkan ahklak yang mulia serta mengawasi teman pegaulannya. Kesembilan Suami istri harus saling memberi dan menerima nasehat dengan ikhlas dan mengembalikan permasalahan ke dalam agama jika memang sudah tidak menemukan solusinya. Kesepuluh Berkomitmen menjalankan rumah tangga bersama-sama dalam mengarungi badai dan gelombang kehidupan.

\section{DAFTAR PUSTAKA}

Ath- Thabrani, Mu'jamul Ausath, Riyadh : Maktabah al Maarif, $1405 \mathrm{H}$.

Bukhari, Shahih Al Bukhori, Kairo : Darul al Hadits, 1422 H

Departemen Agama RI, Al- Qur'an dan terjemah, Semarang C V Asyfa th 1999

Ibnu Hiban, Mawariduzh Zham'an ila Zawa' id, Beirut : Dar al-Kutub Ilmiyah. tt.

Imam Ahmad bin Hambal asy-Syaibani, Musnad Ahmad, Beirut : Dar al- Fikr, tt

Khoiruddin Bashori, Makalah Langkah-langkah Menuju Keluarga Sakinah, 2013. 
Muhammad Nasiruddin al-Albani, Shahih al-Adaabul Mufrad, Arabiyah : Dar ash - Shidiq, 1405 H.

Muhammad Thalib, Menejemen Keluarga Sakinah, Penerbit Pro-U, Cetakan ke 2, 2008.

Sadiman, Arif. Dkk, Media Pendidikan: Pengertian, Pengembangan, dan Pemanfaatannya, Jakarta : Raja Grafindo Persada, 2009.

Sumarso, Pola kehidupan keluarga cerai dan dampak psikologis terhadap siswa, Program pascasarjana, UMY, 2013.

Syaikh Al - Albani, Irwa'ul Gholil fi Takhrij Ahadits Manaris Sabil, Beirut : Al - Maktab al - Islami,1405.

, Silsilah al-Ahadits ash-Shahihah, Riyadh : Maktabah Ma'arif, tt

Zain, Emma \& Sati, Djaka Dt. Ilmu mendidik (Metode Pendidikan), Jakarta : Mutiara Sumber Widya, 1997. 